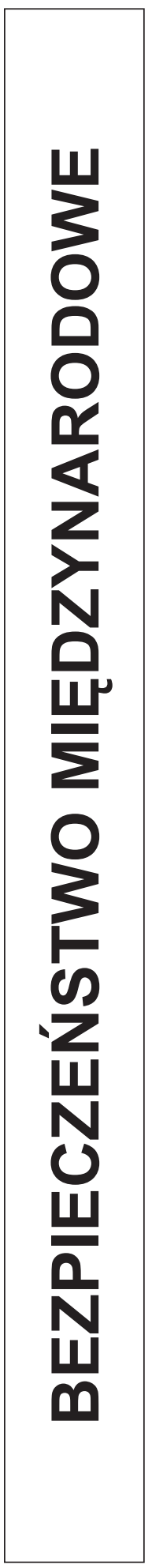





\section{PROBLEMY BEZPIECZEŃSTWA UNII EUROPEJSKIEJ}

W ostatnich latach pojawiają się kolejne publikacje dotyczące europejskiej polityki bezpieczeństwa. Na ten temat wypowiadają się analitycy wojskowi i cywilni. Wśród specjalistów polskich wymienić należy Romana Kuźniara, Stanisława Kozieja, Jerzego Stańczyka, Bolesława Balcerowicza, Donatę Rossę-Kilian i Romana Ziębę.

Unia Europejska, w odróżnieniu od Paktu Północnoatlantyckiego, nie jest sojuszem polityczno-wojskowym i nigdy nie miała takich aspiracji. Jednak już na początku swego istnienia jej państwa członkowskie zdały sobie sprawę, jak ważnym elementem życia jest bezpieczeństwo, które jest warunkiem dobrobytu i wolności społeczeństwa demokratycznego. Organizacja już od pół wieku próbuje objąć integracją sferę bezpieczeństwa i obronności. Już w 1952 r. przedstawiciele państw wchodzących w skład Europejskiej Wspólnoty Węgla i Stali podpisali w Paryżu traktat dotyczący ustanowienia Europejskiej Wspólnoty Obronnej. Dążył on do utworzenia wspólnej europejskiej armii pod kierunkiem wspólnego ministra obrony. Plan zintegrowania militarnego państw nie powiódł się, gdyż projekt mocno ingerował w prawa narodowe ówczesnych państw ${ }^{1}$.

Przez dalsze cztery dekady o utrzymaniu równowagi w Europie decydowały dwie rywalizujące ze sobą strony: Układ Warszawski i NATO. Rozpad systemu dwubiegunowego (zimnowojennego) stworzył nowe możliwości w kwestii bezpieczeństwa europejskiego. Rolę hegemona w świecie przejęły Stany Zjednoczone. Sądzono, że nie będzie to stan przejściowy. Nastąpił rozwój nowej dyscypliny - polemologii, czyli nauki o pokoju. Rozpoczął się powolny proces instytucjonalizacji bezpieczeństwa europejskiego. Platformą dialogu państw europejskich stała się KBWE. Od listopada 1990 r. w Paryżu członkowie przyjęli deklarację o zaprzestaniu traktowania się jako przeciwników, podpisując także Traktat o Konwencjonalnych Siłach Zbrojnych w Europie ${ }^{2}$.

Rozpoczęto tworzenie wielonarodowych formacji wojskowych. Jak słusznie zauważył Bolesław Balcerowicz, ,powodzenie lub niepowodzenie wielonarodowych formacji wojskowych jest ściśle uzależnione od motywów ich tworzenia"3. W sojuszach i koalicjach wojennych są to wyzwania w obliczu zagrożenia bezpieczeństwa państw; przy tworzeniu sił podczas operacji pokojowych motywem przewodnim jest potrzeba

1 K. Wiaderny-Bidzińska, Polityczna integracja Europy Zachodniej, Toruń 2001, s. 130 i n.

2 R. Zięba, Ksztaltowanie ogólnoeuropejskiego systemu bezpieczeństwa, w: Bezpieczeństwo narodowe i międzynarodowe u schyłku XX wieku, red. D. B. Bobrow, E. Haliżak, R. Zięba, Warszawa 1997, s. 451-458.

${ }^{3}$ B. Balcerowicz, Sity zbrojne w państwie i stosunkach międzynarodowych, Warszawa 2006, s. 99. 
utrzymania pokoju w określonym regionie. W wypadku tworzenia sił wielonarodowych Unii Europejskiej motywy są nieco inne i można ujać je w trzech punktach:

1) międzynarodowe aspiracje Unii Europejskiej w kontekście globalizacji i fragmentyzacji życia międzynarodowego, czyli wzmacnianie tożsamości ważnego aktora stosunków międzynarodowych;

2) dążenie do poszerzenia płaszczyzny integracji o sferę wojskowości;

3) potrzeba zapewnienia bezpieczeństwa.

Co prawda Europa nie jest zagrożona wojną na większą skalę, ale pozostaje zagrożenie terroryzmem, w ostatnich latach niepewna sytuacja na Bałkanach, Afryce Północnej i Bliskim Wschodzie. Poczucie bezpieczeństwa, jakie daje społeczeństwom unijnym NATO, ambicje poszczególnych państw oraz różne wizje wojskowej integracji spowodowały, że tworzenie sił zbrojnych Unii postępuje stosunkowo wolno ${ }^{4}$.

Poligonem doświadczalnym wojskowej integracji jeszcze w ramach Unii Zachodnioeuropejskiej była francusko-niemiecka brygada utworzona w 1989 roku. Do roku 1995 ukończono tworzenie Eurokorpusu, związku operacyjnego składającego się z jednostek pięciu państw (Niemiec, Francji, Belgii, Hiszpanii i Luksemburga). Aktualnie formacja ta pozostaje w dyspozycji NATO i UE.

Rzeczywistym sprawdzianem współpracy europejskiej w dziedzinie bezpieczeństwa stała się wojna w Jugosławii, w ostatniej dekadzie XX wieku. Największym był konflikt w Bośni i Hercegowinie (1992-1996), w którym to interweniowały NATO i UZE (monitorowanie przestrzegania zakazu dostaw broni do objętych embargiem byłych republik Jugosławii oraz pomoc humanitarna dla oblężonego Sarajewa). Wobec nieskuteczności tych działań NATO wprowadziło wojska (14 tys.) zmuszając Serbów bośniackich do zaprzestania walki. Kiedy okazało się, że pokojowe wysiłki Wspólnot Europejskich, KBWE i ONZ nie przyniosły zamierzonych skutków, decyzję o interwencji zbrojnej podjęło NATO. Wojna domowa na Bałkanach podziałała na polityków europejskich jak „kubeł zimnej wody” i zdali oni sobie sprawę ze swojej słabości w tej kwestii ${ }^{5}$.

Traktat z Maastricht (7.02.1992) ustanawiał nie tylko Unię Europejską, ale także jej II filar - Wspólną Politykę Zagraniczną i Bezpieczeństwa. Pół roku później przyjęto w Bonn tzw. „deklarację petersberską”, która umożliwiła angażowanie się Unii w operacje wojskowe poza obszarem państw członkowskich. Państwa zobowiązały się do oddawania do dyspozycji wszystkie rodzaje wojskowych sił o charakterze konwencjonalnym. Praktyczny wymiar realizacji tych zadań nadal zostawał daleki od deklarowanej skuteczności. Interwencja NATO w Kosowie w 1999 roku potwierdziła tylko bezsilność UE wobec konfliktów na naszym kontynencie. Na szczycie państw w Kolonii, w czerwcu 1999 r. państwa członkowskie ustanowiły Europejską Politykę Bezpieczeństwa i Obrony (ESDP). Potwierdzono wówczas, że: „Unia musi mieć zdolność do prowadzenia akcji autonomicznych, popartą wiarygodnymi siłami zbrojnymi, możliwością decydowania o ich użyciu i gotowością zrobienia tego, aby odpowiedzieć na

${ }^{4}$ R. Kuźniar, Polityka i siła. Studia strategiczne - zarys problematyki, s. 237-238.

5 Szerzej: S. Wojciechowski, Integracja i dezintegracja Jugostawii na przełomie XX i XXI wieku, Poznań 2002. 
międzynarodowy kryzys bez względu na uprzedzenia względem akcji wyrażane przez NATO" ${ }^{6}$. Ustalono również tzw. Europejski Cel Operacyjny, zobowiązujący państwa członkowskie do wystawienia, do końca 2003 r. unijnych formacji zbrojnych w sile 50-60 tys. żołnierzy, które byłyby siłami szybkiego reagowania. Podzielone na 15 brygad, miały w ciagu 60 dni uzyskiwać gotowość do rozmieszczenia w rejonie konfliktu. Zdecydowano, że siły te muszą być samowystarczalne i zdolne do działania w strefie zagrożenia przynajmniej przez rok. Siły te miały być przerzucone w rejon potencjalnego konfliktu na pokładach 400 samolotów i ok. 100 okrętów $^{7}$. Na kolejnych spotkaniach ministrów spraw zagranicznych i obrony UE precyzowano szczegóły dotyczące budowy europejskich sił reagowania kryzysowego. Zwolennikiem rozbudowy tej formacji był prezydent Lech Kaczyński, który publicznie wskazywał na konieczność powołania sił unijnych.

W ramach Rady Europejskiej postanowiono utworzyć konkretne organy polityczne i wojskowe:

1) Stały Komitet Polityczny i Bezpieczeństwa (SKPB) w Brukseli, składający się z narodowych przedstawicieli na szczeblu ambasadorów. Będzie on sprawował polityczną i strategiczną kontrolę nad operacjami wojskowymi UE;

2) Komitet Wojskowy złożony z szefów sztabów, który będzie wspierał SKPB w kwestiach wojskowych. Przewodniczący Komitetu będzie referował problemy obronności na posiedzeniach Rady;

3) Sztab Wojskowy, który będzie bezpośrednio kierował akcjami antykryzysowymi ${ }^{8}$. Powołano również grupę ekspertów wspierających, których umiejscowiono przy Sekretariacie Rady Europy.

W rzeczywistości Unia Europejska nie osiaggnęła do 2003 r. zdolności do reagowania na kryzysy na zakładanym wcześniej poziomie. Znaczna część deklarowanych sił i środków antykryzysowych pozostawała na etapie tworzenia lub „na papierze".

W tym czasie NATO podjęło decyzję o utworzeniu sił szybkiego reagowania lliczących 21 tys. żołnierzy (Siły Odpowiedzi NATO). Spowodowało to zmianę Europejskiego Celu Operacyjnego. Postanowiono utworzyć mniejsze i bardziej mobilne oddziały bojowe. $\mathrm{W}$ dniu 22 listopada 2004 r. ministrowie obrony narodowej postanowili ograniczyć ich liczbę do 13 i sformować je do roku 2010.

Brak wiarygodności Europejczyków i brak jednolitej strategii dał znać o sobie już wiosną 2003 r. podczas sporu wokół amerykańskiej interwencji w Iraku. Ostatecznie stwierdzono w Brukseli, że mimo braku agresji na dużą skalę wobec UE, należy stawić czoło nowym zagrożeniom. Zaliczono do nich: terroryzm, nielegalne

${ }^{6}$ Cyt. za J. Dobrowolska-Polak, Działania państw europejskich w celu ochrony i pomocy ofiarom konfliktów zbrojnych, w: Wspótczesna Europa, red. S. Wojciechowski, Poznań 2004, s. 223.

7 J. Stańczyk, Powstanie Grup Bojowych Unii Europejskiej i udział w nich Polski, w: Polska $w$ Unii Europejskiej. Aspekty polityczne, międzynarodowe, społeczno-gospodarcze i wojskowe, pod red. J. M. Fiszera, Warszawa 2009, s. 599-600.

${ }_{8}$ A. Ciupiński, Perspektywy rozwoju sił antykryzysowych Unii Europejskiej, w: Bezpieczeństwo państw i narodów w procesie integracji europejskiej, red. W. Śmiałek, J. Tymanowski, Warszawa, s. 62-65. 
rozpowszechnianie broni masowego rażenia, istnienie tzw. państw upadłych i zorganizowaną przestępczość.

Ataki z 11 września 2001 roku rozpoczęły nowy etap instytucjonalizacji bezpieczeństwa europejskiego. Dziesięć dni później na szczycie szefów państw i rządów w Brukseli przyjęto tzw. Plan Działania ds. Walki z Terroryzmem. Wymieniono ponad trzydzieści rodzajów przestępstw, które są elementem działalności grup terrorystycznych, m.in.: porwania dla okupu, branie zakładników, przestępstwa w sieci internetowej, tzw. pranie pieniędzy. Na jego mocy unijne kraje zdecydowały się na wprowadzenie tzw. europejskiego nakazu aresztowania na całym obszarze UE, który od 1 stycznia 2004 r. zastąpił długotrwałe procedury ekstradycyjne między państwami. Usprawniło to znacząco ściganie oraz wydawanie poważnych przestępców. Ponadto każde z państw członkowskich UE musiało dostosować swój system prawny, w tym kodeks karny, aby ustalić minimum sankcji za tego rodzaju działania.

12 grudnia 2003 roku Rada Europejska przyjęła pierwszą w historii Unii strategię bezpieczeństwa. Dokument pod tytułem „Europejska Strategia Bezpieczeństwa: Bezpieczna Europa w lepszym świecie" opracowany został pod przewodnictwem Javiera Solany. Zdefiniowano i wyodrębniono w nim zagrożenia dla bezpieczeństwa Europy. Wymieniono wśród nich terroryzm, proliferację broni masowego rażenia, konflikty regionalne, upadek państw oraz przestępczość zorganizowaną ${ }^{9}$.

Do zdecydowanych kroków zmusiły także następne zamachy terrorystyczne: 11 marca 2004 r. w Madrycie i 7 lipca 2005 r. w londyńskim metrze. Wkrótce przyjęto „Strategię Unii Europejskiej w zwalczeniu terroryzmu”.

Postanowiono usprawnić system przeciwdziałania i informowania w możliwie jak najkrótszym czasie wszystkich państw członkowskich. W celu usprawnienia tychże działań włączono agencje i ogniwa unijne:

- Europol, czyli Europejski Urząd Policji z siedzibą w Hadze. Powołany został w 1995 roku, lecz działania operacyjne podjął dopiero w 1999 r. Zadaniem tej agencji jest zapewnienie ściślejszej i bardziej efektywnej współpracy w zakresie zapobiegania i zwalczania międzynarodowej przestępczości zorganizowanej, także terroryzmu. Europol nie dysponuje żadnymi siłami wykonawczymi, jest jedynie służbą wspomagającą odpowiednie agendy w państwach członkowskich UE. Funkcjonariusze nie posiadają uprawnień do aresztowań i prowadzenia śledztw. Prowadzą prace analityczne, wymianę informacji i szkolenia. Dopiero po zamachach w stolicach europejskich powołano specjalną grupę zadaniową ds. terroryzmu ${ }^{10}$.

- Europejska Agencja Zarządzania Współpracą Operacyjną na Zewnętrznych Granicach Państw Członkowskich (FRONTEM), powołana rozporządzeniem Rady UE z października 2004 roku. Ma siedzibę w Warszawie a jej celem jest koordynacja i współpraca operacyjna państw w dziedzinie zarządzania granicami zewnętrznymi. Wspomaga w szkoleniu funkcjonariuszy, określa standardy szkoleniowe, przeprowadza analizy ryzyka i zleca badania w tej dziedzinie.

9 R. Kuźnia, Polityka i siła, Warszawa 2005, s. 236-237.

10 Na podstawie Konwencji o Europolu oraz decyzji Rady UE z 22 grudnia 2002 roku w sprawie przekazywania informacji pochodzących z działalności służb bezpieczeństwa i wywiadu w zakresie przestępstw terrorystycznych. 
- Eurojust (Jednostki Współpracy Sądowej) powołany w 2002 r. w celu usprawnienia współpracy pomiędzy organami sadowymi w zakresie dochodzeń i ścigania przestępczości międzynarodowej i zorganizowanej. Siedzibą tego organu jest Haga. Liczy on 27 doświadczonych sędziów, prokuratorów lub oficerów policji o równoważnych kompetencjach. Współpracuje ściśle z Europolem. Interpolem i OLAF (Europejski Urząd ds. Zwalczania Oszustw).

- Europejski Koordynator ds., Zwalczania Terroryzmu powołany 25 marca 2004 roku. Nadzoruje on pracę wszystkich ogniw, doraźnych grup roboczych zajmujących się zjawiskiem terroryzmu w ramach UE. Odpowiada za współpracę z USA i za dialog z państwami arabskimi. Koordynatorowi podlega także Europejskie Centrum Sytuacyjne (STICEN), składające się z oddelegowanych przez państwa funkcjonariuszy. STICEN zajmuje się zbieraniem informacji o wszelkich przejawach kryzysowych, przygotowuje analizy sytuacyjne, a także zbiera dane wywiadowcze. Swoje raporty dostarcza Komitetowi Politycznemu i Bezpieczeństwa oraz Komitetowi Wojskowe$\mathrm{mu} \mathrm{UE}^{11}$.

Wzmocniono współpracę służb policyjnych i wywiadowczych poszczególnych państw członkowskich (spotkania szefów służb, tworzenie antyterrorystycznych zespołów zadaniowych). Zawarto również umowy z odpowiednikami amerykańskimi o wymianie danych o osobach podejrzanych o terroryzm ${ }^{12}$.

Do działań systemowych w zakresie zwalczania terroryzmu należy zaliczyć prace legislacyjne w ramach UE. Zmodyfikowano Europejską Konwencję o Zwalczaniu Terroryzmu, a w 2003 roku utworzono Komitet Ekspertów ds. Terroryzmu, który za swój główny cel uznaje wypełnienie wszelkich luk prawnych w europejskim systemie prawnym zwalczającym terroryzm. Najważniejszym efektem owych poczynań jest wprowadzenie Europejskiego Nakazu Aresztowania (13 czerwiec 2002 r.). Akt ten uprościł postępowanie w sprawie wydawania terrorystów. Poprzednio odbywało się to w oparciu o przepisy ekstradycyjne i trwało nawet 10 miesięcy, teraz wydanie terrorysty następuje automatycznie po otrzymaniu wniosku (ENA). Lista czynów przestępczych obejmuje 32 czyny przestępcze, m.in. udział w organizacjach przestępczych, terroryzm, nielegalny przemyt broni i amunicji oraz narkotyków, morderstwa, korupcje i przestępstwa komputerowe ${ }^{13}$.

W dniu 23 listopada 2001 roku w Budapeszcie podpisano Konwencję w Sprawie Cyberprzestępstw. Był to pierwszy akt prawa międzynarodowego dotyczący przestępstw popełnionych przy udziale Internetu i innych sieci komputerowych. W Unii Europejskiej problemy bezpieczeństwa teleinformacyjnego podejmowane są głównie przez wyspecjalizowaną Europejską Agencję Bezpieczeństwa Sieci i Informacji, powołaną w 2004 roku $^{14}$.

${ }^{11}$ K. Liedel, Misja ewaluacyjna UE dotyczaca zdolności Polski w zakresie zwalczania terroryz$m u$, http://www.terroryzm.com/article/279 (dostęp 14.03.2008 r).

12 J. Barcik, Akt terrorystyczny i jego sprawca w świetle prawa międzynarodowego wewnętrznego, Warszawa 2004, s. 53.

${ }_{13}$ K. Kuczyński, Znaczenie ENA w zwalczaniu terroryzmu w Unii Europejskiej, „Studia Europejskie” 2005, nr 1, s. 64 i n. Wydanie osoby winno odbyć się w ciągu 10 dni od podjęcia decyzji.

${ }_{14} \mathrm{~K}$. Silicki, Unia Europejska a bezpieczeństwo teleinformatyczne-inicjatywy i wyzwania, w: Bezpieczeństwo teleinformatyczne państwa, red. M. Madej, M. Terlikowski, Warszawa 2009, s. 189-204. 
Do tej pory UE przeprowadziła kilka operacji pod własnym sztandarem, także z udziałem Polaków. W 2003 roku siły unijne przeprowadziły na terenie Macedonii operację „Concordia”, polegającą głównie na ochronie obserwatorów międzynarodowych z OBWE UE. Uczestniczyło w niej ponad 350 żołnierzy z trzynastu państw unijnych, w tym Polski. W dniu 1 stycznia 2003 r. rozpoczęto operację w Bośni i Hercegowinie z udziałem ponad 500 policjantów z trzydziestu państw, w tym 15 unijnych. Budżet tej operacji wyniósł $30 \mathrm{mln}$ euro, w tym $20 \mathrm{mln}$ pochodziło z kasy UE. Trzecim przedsięwzięciem unijnym w 2003 roku była interwencja humanitarna w Demokratycznej Republice Konga. Decyzją Rady Europejskiej z 12 czerwca 2003 r. rozmieszczono w północno-wschodniej części tego kraju 1800 żołnierzy z Francji, Niemiec, Belgii, Grecji, Szwecji, Wielkiej Brytanii oraz RPA, Brazylii i Kanady ${ }^{15}$. Zdołano zapobiec rzezi etnicznej w tym kraju. Nie powtórzyła się już sytuacja z Rwandy. Sukces misji kongijskiej był zaskoczeniem zarówno dla USA, jak i postronnych obserwatorów. Dla państw Starego Kontynentu sukces ten stał się impulsem do kolejnych działań tego rodzaju. W roku 2006 przeprowadzono również w Kongu operację „Benga” z udziałem 130 żołnierzy polskich. Ich celem było zapewnienie bezpieczeństwa podczas demokratycznych wyborów w tym afrykańskim kraju. Rok później rozpoczęto, także z udziałem około 400-osobowego kontyngentu polskiego, operację w Czadzie. W tym wypadku chodziło o zapewnienie dostaw międzynarodowej pomocy humanitarnej ${ }^{16}$.

Samodzielność militarna UE wpłynęła w pewien sposób na stosunki tej organizacji ze Stanami Zjednoczonymi. Symptomatyczne dla stosunków USA-UE było to, że Stany Zjednoczone sprzeciwiły się przejęciu przez siły europejskie odpowiedzialności za stabilizację w Bośni i Hercegowinie. Obawiały się sukcesu europejskich sojuszników, a także nie miały pewności, czy państwa UE zdołają zapewnić spokój w tym subregionie. Waszyngton wyraził taką zgodę dopiero w momencie zaangażowania się USA w Iraku.

Jak poprzednio wspomniano nowym pomysłem jest tworzenie Grup Bojowych UE. Wchodzą one w skład Europejskich Sił Szybkiego Reagowania. Mają one przystępować do operacji wojskowych nie później niż dziesięć dni od momentu podjęcia decyzji o jej przeprowadzeniu. Jako siły ekspedycyjne realizować będą autonomiczne operacje w zasięgu $6000 \mathrm{~km}$ od Brukseli. Jednostki liczące po 1500-2000 żołnierzy będą szybkimi i mobilnymi siłami antykryzysowymi UE. W celu spełnienia tych założeń UE powinna posiadać strategiczny transport powietrzny i morski. Jedynie szybki przerzut tych grup może zapewnić powodzenie operacji antykryzysowych.

Początkowo Francja, Niemcy i Wielka Brytania proponowały, aby obszarem ich działania był kontynent afrykański, jednak pozostali członkowie UE zdecydowali o niestosowaniu ograniczeń geograficznych.

Udział państw członkowskich w tworzeniu grup jest dobrowolny. Grupy bojowe tworzone są w trójnasób:

1) poprzez powołanie grupy narodowej, z jednego państwa członkowskiego (Francja, Hiszpania, Włochy i Wielka Brytania);

15 J. Dobrowolska-Polak, Działania..., op. cit., s. 221-222

16 D. Rossa-Kilian, Wyzwania i zagrożenia w II filarze Unii Europejskiej oraz ich wplyw na ksztalt polskiej polityki bezpieczeństwa w latach 2000-2007, w: Polska w Unii..., op. cit., s. 590. 
2) utworzenie grupy wielonarodowej pod dowództwem jednego państwa, tzw. wiodącego, które odpowiedzialne jest za formowanie i działanie grupy;

3) grupa wielonarodowa dowodzona rotacyjnie, np. grupy:

- nordycka (Szwecja, Finlandia, Norwegia i Estonia),

- bałkańska (Grecja, Bułgaria, Cypr i Rumunia),

- morska (Włochy, Hiszpania, Grecja i Portugalia),

- Francja i Belgia,

- Niemcy, Czechy i Austria,

- Wielka Brytania i Holandia.

Łącznie powstaje 17 grup bojowych, z których UE dysponować będzie ok. 22 tys. żołnierzy. Są one tworzone przez 24 państwa unijne i Norwegię. Niektóre z państw wydzieliły do grup jednostki specjalistyczne, np. Finlandia - jednostkę do zwalczania zagrożeń chemicznych i biologicznych; Grecja - Centrum Koordynacyjne Transportu Morskiego; Cypr - grupę sanitarną, a Litwa - grupę uzdatniania wody pitnej. Od 1 stycznia 2010 roku grupy bojowe pełnią rotacyjnie dyżury w trybie sześciomiesięcznym.

W grudniu 2006 r. podjęto decyzję o utworzeniu tzw. Weimarskiej Grupy Bojowej, w skład której wejdą trzy bataliony: francuski, niemiecki i polski. Grupa ta ma osiągnąć pełną zdolność bojową w 2013 roku. Będzie to jednostka szybkiego reagowania. Żołnierze całej grupy mają być dowodzeni online, poprzez system BMS (Battle Management System). Dużym usprawnieniem kierowania jest to, że dowódca widzi ruchy każdego z żołnierzy, śledzi też ruchy przeciwnika. Łączność BSM zapewnia satelita lub bezzałogowy pojazd latający. Dowodzenie elektroniczne wprowadziły do tej pory niektóre armie, m.in. USA (Afganistan, Irak) i Izraela. Do tej pory elektroniczny system dowodzenia istniał w wojsku polskim na szczeblu brygad i dywizji. Nosi nazwę „Szafran” i służy do przekazywania informacji na poziomie sztabów. Teraz ma zejść na poziom pojedynczego żołnierza, na początek w polskim batalionie wchodzącym w skład tej grupy bojowej ${ }^{17}$.

To zwiększone zaangażowanie Polski w militarne przedsięwzięcia wydaje się ważne dla realizacji naszych interesów narodowych. Stworzyła się szansa na poprawienie współpracy z Francją i Niemcami, państwami wiodącymi w Unii Europejskiej. Te dwa państwa są motorem integracji europejskiej. Ich rola nieco osłabła po porażce projektu Traktatu Konstytucyjnego. Osłabła także oś Paryż-Berlin-Moskwa i daje to Polsce szansę na budowę silniejszej pozycji w ramach $\mathrm{UE}^{18}$.

Kolejną grupą z udziałem Polski ma być tzw. Grupa Wyszehradzka (Czechy, Słowacja, Węgry i Polska). Zakłada się, że osiagnie ona zdolność bojową w 2015 roku. $\mathrm{W}$ dalszej perspektywie planowane jest zaproszenie Ukrainy ${ }^{19}$.

17 Wiceminister obrony narodowej Marcin Idziak zapowiedział zakup systemu dla naszego wojska w końcu 2011 roku. Patrz: M. Górka, Nasza cyfrowa armia, „Gazeta Wyborcza” z 15 lutego 2011 r., s. 3.

18 J. Stańczyk, Powstanie grup..., op. cit., s. 610-611.

19 Szefowie sztabów państw Grupy Wyszehradzkiej omawiali tę propozycję w Sliač na Słowacji (26-28.01.2006). W roku następnym rozpoczęto przygotowania w tym kierunku. M. Kawałowski, Zaangażowanie Polski w Grupach Bojowych Unii Europejskiej, „Zeszyty Naukowe AON” 2007, nr 3, s. 56. 
Niezdolność państw UE do szybkiego przerzutu znacznych sił ekspedycyjnych na odległość kilku tysięcy kilometrów zdecydowała o modyfikacji pierwotnego celu transportu ponad 50 tys. żołnierzy na tak duże odległości. Słabości transportu unijnego mogą być zrekompensowane poprzez wykorzystanie baz państw europejskich w różnych regionach świata (Francji, Wielkiej Brytanii i Holandii). Do przetransportowania Grupy Bojowej (żołnierzy, sprzętu wojskowego, zaopatrzenia) należy wykonać około 200 lotów samolotami transportowymi typu Herkules C-130 lub ponad 30 lotów samolotami Boeing C-17 Globmaster. Dysponują nim tylko Brytyjczycy i może przewieźć na pokładzie ładunek 84 ton. Aby podnieść zdolności transportowe sił unijnych podjęto program budowy samolotu transportowego Airbus A-400M. Zaplanowano, że do 2020 roku zostanie wyprodukowanych 80-100 takich maszyn. Ten nowy samolot „unijny” zdolny będzie przewieźć na pokładzie ponad 40 ton. Będzie on trzykrotnie mniejszy od udostępnianego przez Ukrainę Rusłana An-24, który zabiera aż 130 ton. Tymczasowym rozwiązaniem jest korzystanie na podstawie porozumienia „Berlin plus" z zasobów NATO, czyli pośrednio amerykańskich. Inną opcją jest korzystanie z ukraińskich lub rosyjskich samolotów typu An-24.

Kolejnym niedostatkiem sił unijnych jest brak środków nowoczesnej łączności i rozpoznania, własnego zwiadu satelitarnego. Powołana przez Radę UE w lipcu 2004 r. Europejska Agencja Obrony realizuje budowę satelitarnego systemu rozpoznawczego Galileo. Miał osiagnąć zdolność operacyjną w końcu 2008 roku, jednak tak się nie stało. Należy sądzić, że powodem jest niedostatek środków finansowych. Zadaniem Europejskiej Agencji Obrony jest wspomaganie w rozwijaniu europejskiej polityki uzbrojenia, wspieranie badań w tym zakresie, koordynacja współpracy przemysłów obronnych państw członkowskich, tak by nie dublowały się przedsięwzięciami. Dublowanie zadań jest nadal mankamentem wielu programów. Na przykład w UE istnieją aż 22 programy budowy transportera opancerzonego, 6 budowy samolotów bezzałogowych, 3 myśliwców wielozadaniowych. W roku 2008 Agencja dysponowała budżetem ponad 20 miliardów euro, czyli trzykrotnie większym niż budżet polskiego MON. Powyższe słabości w zakresie zdolności operacyjnych sił unijnych skazują na konieczność ścisłej współpracy z USA i NATO. Zgodnie z założeniem Europejskiego Celu Operacyjnego przy natowskim dowództwie SHAPE (Supreme Headquarters Allied Powers Europe) przystapiono do tworzenia unijnej komórki planowania operacyjnego ${ }^{20}$.

Problematyka bezpieczeństwa i obrony nabiera w wypadku Polski dużego znaczenia w związku z objęciem przez nasz kraj prezydencji w UE już od 1 lipca tego roku. Priorytety wynikające z polskiej prezydencji przedstawił 7 marca $2011 \mathrm{r}$. minister obrony narodowej Bohdan Klich w Akademii Obrony Narodowej w Rembertowie podczas inauguracji kursu Wysokiego Szczebla Europejskiego Kolegium Bezpieczeństwa i Obrony. Przygotowania Polski do przewodnictwa w Radzie Europy w zakresie obronności trwały już od 2009 roku. Wyartykułowany wówczas cel główny dla Polski brzmiał: zmobilizowanie NATO do lepszego traktowania Europy Środkowej i poprawa zdolności wojskowych Unii Europejskiej. Zaplanowano ponad 200 przedsięwzięć, kursów, spotkań różnego szczebla, na które zaplanowano wydać 400 milionów złotych.

20 A. Konarzewska, Grupy Bojowe Unii Europejskiej. Zaczqtek euroarmii?, „Bezpieczeństwo Narodowe" 2007, nr 3-4, s. 156-158. 
Ambitnie zakładano, że nasza prezydencja będzie się różnić od poprzednich tym, że w trakcie prezydencji będziemy wcielać w życie określone decyzje, a nie dopiero je uzgadniać. Dyrektor Departamentu Polityki Bezpieczeństwa MSZ Adam Kobieracki mówił: „Nie chcemy tak jak Francuzi dwa lata temu, przygotować tylko pięknej i ambitnej deklaracji, która jest ogłaszana na początku prezydencji $[\ldots] \mathrm{w}$ połowie 2011 roku powinien jednak nadejść czas żniw tego, co teraz siejemy”21.

Wśród najważniejszych propozycji polskich wymieniano:

- utworzenie stanowiska zastępcy do spraw wojskowych wysokiego przedstawiciela Unii Europejskiej ds. polityki zagranicznej i bezpieczeństwa (Catherine Ashton). W składzie Europejskiej Służby Działań Zewnętrznych stworzyć pion ds. wojskowych, odpowiednik attache wojskowych;

- powołanie Europejskiego Dowództwa Operacyjnego. Nie chodziło tutaj o scentralizowanie europejskich armii, a nadzorowanie misji cywilnych i wojskowych;

- reforma grup bojowych poprzez rozszerzenie ich o komponent powietrzny i morski. Zmodernizowane grupy bojowe będą punktem wyjścia do tworzenia Europejskich Sił Stabilizacyjnych;

- ściślejsze określenie współpracy NATO z UE, czyli zmodyfikowanie formuły Berlin Plus;

- rozwój Partnerstwa Wschodniego, polegający na zacieśnieniu współpracy z Armenią, Azerbejdżanem, Gruzją, Mołdawią i Ukrainą. Ma zapewnić współpracę z tymi państwami, ale do niczego ich nie zmuszać;

- stworzenie mechanizmu solidarności energetycznej. Postulat najtrudniejszy do zrealizowania, bowiem wiążą się z nim ogromne wydatki. Inaczej mówiąc: fizyczne połączenie z gazociagami Europy Zachodniej, a przez dostęp do surowca z Norwegii i Bliskiego Wschodu, spowodowałby spadek naszej zależności od Rosji ${ }^{22}$.

Kwestie bezpieczeństwa zostały wcześniej uznane przez polski MSZ za jedno z pięciu zadań naszej prezydencji.

Mimo tych przedsięwzięć tak zwana obrona europejska jest w chwili obecnej perspektywicznym postulatem, ambitnym celem formułowanym przez część kręgów politycznych obecnej Unii Europejskiej. Należy jednak stwierdzić, że w najbliższych latach nie powstanie europejska armia pod jednolitym dowództwem i jednakowo umundurowana. Nie będzie dwóch NATO, czyli obok sił zintegrowanych Sojuszu Północnoatlantyckiego, równolegle nie powstaną siły zbrojne UE.

Należy sądzić, że politycy unijni być może świadomie przyjęli rolę drugoplanową w rozwiązywaniu kryzysów na świecie. Zadecydowały ograniczone możliwości tworzonego potencjału militarnego Europejczyków. Tym samym UE przyjęła na siebie zadania uzupełniające w stosunku do operacji prowadzonych przez Organizację Narodów Zjednoczonych, Stany Zjednoczone, czy przez NATO. Być może przyjęte rozwiązania są niezbędnym kompromisem, aby w stopniu minimalnym być efektywnym w przyjętych na siebie zobowiązaniach antykryzysowych w środowisku międzynarodowym.

${ }^{21}$ Nawróceni na Europę, „Polska Zbrojna”, nr 21 z 23.05.2010 r., s. 10.

22 Ibidem, s. 13. 


\title{
STRESZCZENIE
}

W ostatnich dwóch dekadach nastapił w Unii Europejskiej rozwój instytucji odpowiadających za bezpieczeństwo tych społeczeństw. W roku 2003 Rada Europy przyjęła pierwszą w historii tej organizacji międzynarodowej strategię bezpieczeństwa. Do zdecydowanych kroków zmusiły także zamachy terrorystyczne. Istotnego znaczenia nabrał proces tworzenia unijnych formacji wojskowych, głównie Grup Bojowych. Tworzenie tej formacji jest najważniejszą, podejmowaną przez UE inicjatywą militarną. Od 2010 roku pełnią one rotacyjne dyżury i są zdolne do szybkiego reagowania na kryzysy poza terytorium Europy. W procesie tym coraz aktywniej uczestniczy Polska, przyczyniając się do umacniania swej pozycji w strukturach UE. Polska tworzy z innymi krajami Weimarską i Wyszehradzką Grupę Bojową.

Należy sądzić, że w najbliższych latach nie powstanie europejska armia pod jednolitym dowództwem i jednakowo umundurowana. Unia Europejska przyjęła na siebie zadania uzupełniające w stosunku do operacji wojskowych prowadzonych przez Organizację Narodów Zjednoczonych, Stany Zjednoczone i Sojusz Północnoatlantycki.

\section{PROBLEMS OF THE EU SECURITY}

\begin{abstract}
The institutions responsible for the security of those societies developed in the last two decades in the European Union. The Council of Europe accepted the first safety strategy in the history of this international organization. Terrorist attacks made taking forceful steps necessary. The process of creating union troops mainly in combat groups became significant. The creation of this group is the most important military initiative undertaken by the European Union. Since 2010 they have been working in rotation groups and with the ability to react quickly during a crisis outside European territory. Poland is taking part in this process with an increasingly active contribution to strengthen its position within EU structures. Poland is part of the Weimarsk and Visegrad combat group with other countries.

There is no sign yet of the creation of a unileteral European army in the coming years. The European Union undertakes supplementary tasks in relation to military operations run by the United Nations and NATO.
\end{abstract}

